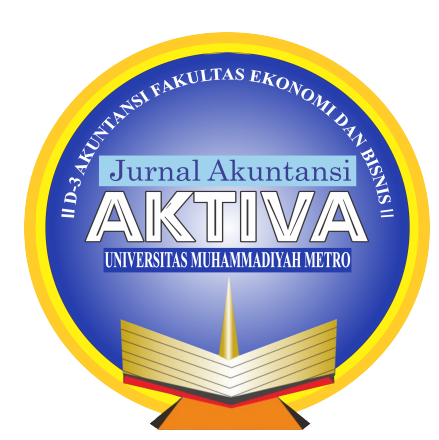

Jurnal Akuntansi AKTIVA, Vol 1, No 1, April 2020

\title{
ANALISIS RASIO LIKUIDITAS PADA PT INDOFOOD SUKSES MAKMUR
}

\author{
${ }^{1}$ Yordan Haryono, ${ }^{2}$ Nedi Hendri, ${ }^{3}$ Ardiansyah Japlani \\ Universitas Muhammadiyah Metro, J1. Ki Hajar Dewantara, 34111, Lampung, Indonesia \\ Universitas Muhammadiyah Metro, Jl. Ki Hajar Dewantara, 34111, Lampung, Indonesia \\ Universitas Muhammadiyah Metro, Jl. Ki Hajar Dewantara, 34111, Lampung, Indonesia \\ Email: haryonoyordan@gmail.com nedi_hendri@yahoo.com.japlani_2006@yahoo.co.id
}

\begin{abstract}
This is research was done to measure PT Indofood Sukses Makmur by using Liquidity Ratio Analysis. The data used is a PT Indofood Sukses Makmur financial report triving by 2015-2018. The study is using a Descrptive Quantitative approach. This type of research is a case study. The data-collection procedure for this research is using Documentation Techniques. The results show that PT Indofood Sukses Makmur over the past 4 years has had very good finnancial performance.
\end{abstract}

Keywords: Analysis, Ratio, Likuidity

\section{ABSTRAK}

Penelitian ini dilakukan untuk mengukur tingkat kesehatan PT Indofood Sukses Makmur dengan menggunakan analisis rasio likuiditas. Data yang di gunakan adalah laporan keuangan PT Indofood Sukses Makmur tahun 2015-2018. Penelitian ini menggunakan pendekatan Kuantitatif Deksriptif. Jenis penelitian ini adalah study kasus. Prosedur pengumpulan data pada penelitian kali ini menggunakan teknikn dokumentasi. Penelitian ini menggunakan metode analisis deskriptif dengan pendekatan kuantitatif. Hasil penelitian ini menunjukan bahwa PT Indofood Sukses Makmur selama 4 tahun terakhir memiliki kinerja keuangan yang samgat baik.

Kata Kunci: Analisis, Rasio, Likuiditas

\section{PENDAHULUAN}

Di Indonesia saat ini banyak berdiri perusahaan-perusahaan yang bergerak di berbagai macam sektor. Hal tersebut tentunya dapat membantu meningkatkan perekonomian di Indonesia. Setiap perusahaan pasti memiliki kinerja keuangan masing-masing. Menurut Haq (2013), bagi pihakpihak yang memiliki kepentingan terhadap perkembangan suatu perusahaan sangat perlu untuk mengetahui kondisi kinerja keuangan perusahaan yang tercermin dalam laporan keuangan.

Laporan keuangan merupakan alat yang sangat penting untuk memperoleh informasi sehubungan dengan posisi keuangan dan hasil-hasil yang telah dicapai perusahaan yang 
bersangkutan (Munawir, 2016). Informasi yang tersedia pada laporan keuangan di butuhkan oleh pihak-pihak yang berkepentingan yaitu pihak internal maupun pihak eksternal (investor). Perkembangan perusahaan sangat bergantung pada modal yang ditanamkan oleh investor, sehingga perusahaan harus memiliki kinerja yang baik agar mendapatkan kepercayaan dari investor untuk menanamkan modalnya pada perusahaan. Kondisi keuangan diketahui dari laporan keuangan perusahaan terdiri dari neraca, laporan laba-rugi, laporan perubahan ekuitas, dan laporan arus kas (Barus dkk., 2017). Untuk menilai keberhasilan kinerja perusahaan ataupun sebagai dasar untuk memperbaiki kondisi perusahaan di masa yang akan datang dapat dilakukan melalui analisa rasio keuangan pada laporan keuangan tersebut.

Analisis rasio keuangan adalah bagian dari analisis bisnis atas prospek dan risiko perusahaan untuk kepentingan pengambilan keputusan dengan menstrukturkan tugas analisis melalui evaluasi atas bisnis lingkungan perusahaan, strateginya, serta posisi dan kinerja keuangannya (Subramanyam dan Wild, 2012). Analisis rasio keuangan berguna sebagai alat penghubung untuk mempertanggung jawabkan kinerja laporan keuangan tersebut dan menjadi bahan pertimbangan dalam menentukan kebijakan pada periode selanjutnya. Biasanya laporan keuangan dianalisa setiap persatu periode.

Rasio keuangan menunjukkan kemampuan perusahaan dalam memperoleh laba atau ukuran efektivitas pengelolaan manajemen perusahaan (Barus dkk., 2017). Secara umum rasio keuangan yang sering digunakan untuk menilai kinerja keuangan perusahaan adalah rasio likuiditas, rasio profitabilitas,rasio aktivitas, dan rasio solvabilitas. Namun dalam penelitian ini, penulis hanya menggunakan analisis rasio liquiditas saja. Analisa rasio liquiditas merupakan rasio yang menggambarkan kemampuan perusahaan dalam memenuhi kewajiban jangka pendeknya yang segera jatuh tempo. Rasio likuiditas bertujuan untuk mengetahui kemampuan perusahaan dalam membayar jangka pendek (Hery, 2015). Jika perusahaan dapat memenuhi kewajiban jangka pendeknya tepat waktu maka kondisi keuangan perusahaan tersebut baik. Sebaliknya jika perusahaan tidak dapat memenuhinya berarti kondisi keuangannya tidak baik. Hal itu juga yang akan memberikan jaminan bagi pihak kreditor untuk memberikan pinjaman selanjutnya.

Rasio likuiditas yang umum digunakan yaitu rasio lancar (current ratio), rasio persediaan terhadap modal kerja bersih (inventory to net working capital), rasio kas (cash ratio) dan rasio cepat (quick ratio) (Ikhsan dkk., 2016). Likuiditas tidak hanya berkenaan dengan keadaan keseluruhan keuangan perusahaan, tetapi juga berkaitan dengan kemampuannya untuk mengubah aset lancar menjadi uang kas (Andayani, 2016). Analisis rasio likuiditas dapat dilakukan dalam beberapa periode sehingga terlihat perkembangan likuiditas perusahaan dari waktu ke waktu.

PT Indofood Sukses Makmur merupakan perusahaan yang bergerak di bidang produksi makanan dan minuman. Yang sudah beroperasi sejak awal tahun 1980-an. Saat ini PT Indofood Sukses Makmur telah menjadi sebuah perusahaan total food solution dengan kegiatan operasional yang mencakup seluruh tahapan proses produksi makanan. Mulai dari pengolahan bahan baku 
hingga menjadi produk akhir yang tersedia di rak para pedagang eceran. Perusahaan ini juga mengekspor bahan makanan nya hingga Asia, Australia dan Eropa. Salah satu keberhasilan PT Indofood dalam bidang makanan yaitu produksi mie instan yang menjadi brand image masyarakat. PT Indofood Sukses Makmur merupakan salah satu perusahaan terbesar di indonesia. Hal ini yang membuat penelusis ingin mengetahui kinerja keuangan perusahaan tersebut. Seperti perusahaan perusahaan pada umumnya PT Indofood Sukses Makmur juga menyusun laporan keuangannya untuk memberikan informasi yang terdiri dari neraca, laporan laba-rugi, laporan perubahan ekuitas,dan laporan arus kas. Berdasarkan latar belakang tersebut maka penulis tertarik untuk melakukan penelitian dengan judul "Analisis Rasio Likuiditas pada PT Indofood Sukses Makmur".

\section{LANDASAN TEORI}

2.1 Pengertian Laporan Keuangan

Laporan keuangan merupakan suatu daftar yang di susun oleh akuntan pada akhir periode untuk suatu perusahaan atau catatan yang memberikan informasi keuangan suatu perusahaan yang telah menjalankan perusahaan selama satu periode (Suyanto dan Nusantoro, 2016)".

2.2 Pengetian Analisis Rasio Keuangan

Menurut Munawir (2016), adalah Future oriented atau berorientasi dengan masa depan, artinya bahwa dengan analisis rasio keuangan dapat digunakan sebagai alat untuk meramalkan keadaan keuangan serta hasil usaha dimasa yang akan datang. Dengan angkaangka ratio historis atau kalau memungkinkan dengan angka rasio industri (yang dilengkapi dengan data lainnya) dapat digunakan sebagai dasar untuk penyusunan laporan keuangan yang diproyeksikan yang merupakan salah satu bentuk perencanaan keuangan perusahaan.

2.3 Pengertian Rasio Likuiditas

Menurut Sawir (2009), rasio likuiditas adalah kemampuan perusahaan untuk melunasi kewajiban jangka pendek tepat pada waktunya.Pengendalian yang cukup diperlikan untuk mempertahankan kegiatan dan kelancaran operasional perusahaan yang bertujuan untuk menghindari adanya tindakan tindakan penyelewengan atau penyalahgunaan oleh karyawan perusahaan. Apabila semakin besar kemampuan perusahaan dalam membayar hutang jangka pendeknya maka akan mempengaruhi berbagai kemungkinan perusahaan akan mendapatkan pembiayaan dari para kreditur jangka pendek untuk mengoprasikan kegiatan usahanya. Rasio likuiditas dapat dihitung berdasarkan informasi modal kerja pos pos aktiva lancar dan hutang lancar.

2.4 Jenis-Jenis Rasio Likuiditas

\subsubsection{Current Ratio (Rasio Lancar)}

Current ratio merupakan perbandingan antara aktiva lancar dan kewajiban lancar dan merupakan ukuran yang paling umum digunakan untuk mengetahui kesanggupan suatu perusahaan memenuhi kewajiban jangka pendeknya. Current ratio menunjukkan sejauh mana akitva lancar menutupi kewajiban-kewajiban lancar.Semakin besar perbandingan aktiva lancar dan kewajiban lancar semakintinggi kemampuan perusahaan menutupi kewajiban jangka pendeknya. Current ratio yang rendah biasanya dianggap menunjukkan terjadinya masalah dalam likuidasi, sebaliknya current ratio yang terlalu tinggi juga kurang bagus, karean menunjukkan banyaknya dana menganggur yang pada akhirnya dapat mengurangi kemampulabaan perusahaan (Sawir, 2009). 


\subsubsection{Quick Ratio (Rasio Cepat)}

Rasio ini disebut juga acid test rasio yang juga digunakan untuk mengukur kemampuan suatu perusahaan dalam memenuhi kewajiban jangka pendeknya. Penghitungan quick ratio dengan mengurangkan aktiva lancar dengan persediaan. Hal ini dikarenakan persediaan merupakan unsur aktiva lancar yang likuiditasnya rendah dan sering mengalami fluktuasi harga serta menimbulkan kerugian jika terjadi likuiditas. Jadi rasio ini merupakan rasio yang menunjukkan kemampuan aktiva lancar yang paling likuid mampu menutupi hutang lancar. Sawir (2009), Mengatakan bahwa quick ratio umumnya dianggap baik adalah semakin besar rasio ini maka semakin baik kondisi perusahaan.

\subsubsection{Cash Ratio (Rasio Kas)}

Rasio ini merupakan rasio yang menunjukkan posisi kas yang dapat menutupi hutang lancar dengan kata lain cash ratio merupakan rasio yang menggambarkan kemampuan kas yang dimiliki dalam manajemen kewajiban lancar tahun yang bersangkutan (Sawir, 2009).

\section{METODE PENELITIAN}

\subsection{Jenis Penelitian}

Pada penelitian kali ini jenis penelitian yang digunakan adalah studi kasus. Penelitian ini memusatkan diri secara intensif pada satu objek tertentu yang mempelajari nya sebagai suatu kasus (Nawawi, 2003).

\subsection{Metode Penelitian}

Metode penelitian yang digunakan adalah metode kuantitatif. Metode penelitian kuantitatif disajikan dengan angka-angka, mulai dari pengumpulan data, penafsiran terhadap data tersebut, serta penampilan hasilnya (Arikunto, 2006).

\subsubsection{Objek dan Lokasi Penelitian}

Objek pada penelitian kali ini adalah data laporan keuangan PT Indofood Sukses Makmur periode 2015 - 2018 yang peneliti peroleh dari Galeri Investasi Universitas Muhammadiyah Metro dan situs resmi perusahaan.

\subsubsection{Populasi dan Sampel}

Populasi pada penelitian ini adalah seluruh laporan keuangan PT Indofood Sukses Makmur. Sedangkan sampel pada penelitian ini adalah laporan keuangan PT Indofood Sukses Makmur pada periode 2015-2018.

\subsubsection{Prosedur Pengumpulan Data}

Prosedur pengumpulan data pada penelitian kali ini menggunakan teknik dokumentasi. "Dengan teknik dokumentasi ini peneliti dapat memperoleh informasi dari macam-macam sumber tertulis atau dari dokumen yang ada pada informan" (Ridwan, 2006). Data yang di kumpulakan terdiri atas laporan keuangan PT Indofood Sukses Makmur periode 2015-2018 melalui Galeri Investasi Universitas Muhammadiyah Metro.

\section{HASIL DAN PENELITIAN}

4.1 Tabel penelitian

4.1.1 Tabel aktiva PT Indofood Sukses Makmur 


\section{TABEL 4.2}

$\begin{array}{llll}\text { Tahun } & \text { Aktiva Lancar } & \text { Aktiva Tidak Lancat } & \text { Total Aktiva } \\ 2015 & 13.961 .500 .000 .000 & 12.599 .124 .000 .000 & 26.560 .624 .000 .000 \\ 2016 & 15.571 .362 .000 .000 & 13.330 .586 .000 .000 & 28.901 .948 .000 .000 \\ 2017 & 16.579 .331 .000 .000 & 15.040 . .183 .000 .000 & 31.619 .514 .000 .000 \\ 2018 & 14.121 .568 .000 .000 & 20.045 .585 .000 .000 & 34.367 .153 .000 .000\end{array}$

Sumber : Laporan keuangan PT indofood Sukses Makmur

4.1.2 Tabel Aktiva PT Indofood Sukses Makmur

TABEL 4.2

$\begin{array}{llll}\text { Tahun } & \text { Aktiva Lancar } & \text { Aktiva Tidak Lancat } & \text { Total Aktiva } \\ 2015 & 13.961 .500 .000 .000 & 12.599 .124 .000 .000 & 26.560 .624 .000 .000 \\ 2016 & 15.571 .362 .000 .000 & 13.330 .586 .000 .000 & 28.901 .948 .000 .000 \\ 2017 & 16.579 .331 .000 .000 & 15.040 . .183 .000 .000 & 31.619 .514 .000 .000 \\ 2018 & 14.121 .568 .000 .000 & 20.045 .585 .000 .000 & 34.367 .153 .000 .000\end{array}$

Sumber : Laporan keuangan PT indofood Sukses Makmur

4.1.3 Tabel Liabilitas PT Indofood Sukses Makmur

TABEL 4.2

$\begin{array}{cccc}\text { Tahun } & \text { Hutang Lancar } & \begin{array}{c}\text { Hutang Jangka } \\ \text { panjang }\end{array} & \text { Total Hutang } \\ 2015 & 6.002 .344 .000 .000 & 4.171 .369 .000 .000 & 10.173 .713 .000 .000 \\ 2016 & 6.469 .785 .000 .000 & 3.931 .340 .000 .000 & 10.401 .125 .000 .000 \\ 2017 & 6.827 .588 .000 .000 & 4.467 .596 .000 .000 & 11.295 .184 .000 .000 \\ 2018 & 7.235 .398 .000 .000 & 4.424 .605 .000 .000 & 11.660 .003 .000 .000\end{array}$

Sumber : Laporan keuangan PT indofood Sukses Makmur

4.2 Perhitungan

\subsubsection{Rasio Likuiditas}

Analisa rasio liquiditas merupakan rasio yang menggambarkan kemampuan perusahaan dalam memenuhi kewajiban jangka pendeknya yang segera jatuh tempo. Rasio likuiditas bertujuan untuk mengetahui kemampuan perusahaan dalam membayar jangka pendek (Hery, 2015).

a. Current RatioCurrent ratio menunjukkan sejauh mana akitva lancar menutupi kewajiban-kewajiban.

$$
\text { Current Ratio }=\frac{\text { aktiva lancar }}{\text { hutang lancar }} \times 100 \%
$$

1. Tahun 2015

$$
\text { Current Ratio }=\frac{13.961 .500 .000 .000}{6.002 .344 .000 .000} \times 100 \%
$$


2. Tahun 2016

$$
=232,6 \%
$$

$$
\begin{aligned}
\text { Current Ratio }= & \frac{15.571 .362 .000 .000}{6.469 .785 .000 .000} \times 100 \% \\
& =240 \%
\end{aligned}
$$

3. Tahun 2017

$$
\begin{aligned}
\text { Current Ratio }= & \frac{16.579 .331 .000 .000}{6.827 .588 .000 .000} \times 100 \% \\
& =242,8 \%
\end{aligned}
$$

4. Tahun 2018

$$
\begin{aligned}
\text { Current Ratio }= & \frac{14.121 .568 .000 .000}{7 \cdot 235.398 .000 .000} \times 100 \% \\
& =195,1 \%
\end{aligned}
$$

b. Quick ratio

Rasio ini merupakan kemampuan perusahaan dalam membayar hutang lancar dengan aktiva lancar tanpa menggunakan persediaan.

$$
\text { Quick Ratio }=\frac{\text { aktiva lancar }- \text { persediaan }}{\text { hutang lancar }} \times 100 \%
$$

1. Tahun 2015

$$
\begin{aligned}
\text { Quick Ratio } & =\frac{13.961 .500 .000 .000-2.546 .835 .000 .000}{6.002 .344 .000 .000} \times 100 \% \\
& =190,1 \%
\end{aligned}
$$

2. Tahun 2016

$$
\begin{aligned}
\text { Quick Ratio } & =\frac{15.571 .362 .000 .000-3.109 .916 .000 .000}{6.469 .785 .000 .000} \times 100 \% \\
& =192,6 \%
\end{aligned}
$$

3. Tahun 2017

$$
\begin{aligned}
\text { Quick Ratio } & =\frac{16.579 .331 .000 .000-3.261 .635 .000 .000}{6.827 .588 .000 .000} \times 100 \% \\
& =195 \%
\end{aligned}
$$

4. Tahun 2018

$$
\begin{aligned}
\text { Quick Ratio } & =\frac{14.121 .568 .000 .000-4.001 .277 .000 .000}{7.235 .398 .000 .000} \times 100 \% \\
& =139,8 \%
\end{aligned}
$$

c. Cash Ratio

Kemampuan kas dalam melunasi hutang lancar nya

$$
\text { Cash Ratio }=\frac{\text { kas }}{\text { hutang lancar }} \times 100 \%
$$


1. Tahun 2015

$$
\begin{aligned}
\text { Cash Ratio } & =\frac{7.657 .510 .000 .000}{6.002 .344 .000 .000} \times 100 \% \\
& =127,5 \%
\end{aligned}
$$

2. Tahun 2016

$$
\begin{aligned}
\text { Cash Ratio } & =\frac{8.371 .980 .000 .000}{6.469 .785 .000 .000} \times 100 \% \\
& =129,4 \%
\end{aligned}
$$

3. Tahun 2017

$$
\begin{aligned}
\text { Cash Ratio } & =\frac{8.796 .690 .000 .000}{6.827 .588 .000 .000} \times 100 \% \\
& =128,8 \%
\end{aligned}
$$

4. Tahun 2018

$$
\begin{aligned}
\text { Cash Ratio } & =\frac{4.726 .822 .000 .000}{7.235 .398 .000 .000} \times 100 \% \\
& =65,3 \%
\end{aligned}
$$

4.3 Pembahasan

\subsubsection{Cash ratio}

Tidak ada standar khusus untuk menentukan current ratio yang paling baik, namun untuk prinsip kehati-hatian, "maka besarnya current ratio sekitar 200\% dianggap sangat baik" (Kasmir, 2008). Semakin tinggi rasio ini maka semakin baik kinerja keuangan perusahaannya. pada tahun 2015 PT indofood memiliki current ratio sebesar 232,6\%. Dari data tersebut dapat kita ketahui bahwa current ratio dianggap sangat baik dari standar baik 150\%. berarti setiap Rp. 1 lancar di jamin dengan Rp. 2,3 aktiva lancar. Pada tahun selanjutnya/2016 current ratio mengalami peningkatan sebesar 7,4\% selisih dari 232,6\% - 240\%. Dari data tersebut dapat di ketahui bahwa current rasio di anggap sangat baik dari standar baik current ratio yaitu $150 \%$. berarti setiap Rp. 1 lancar di jamin dengan Rp. 2,4 aktiva lancar. Kemudian pada tahun 2016 ketahun 2017 current ratio mengalami peningkatan sebesar 2,8\% selisih dari $240 \%$ - 242,8\%. Dari data tersebut dapat di ketahui bahwa current rasio di anggap sangat baik dari standar baik current ratio yaitu 150\%. berarti setiap Rp. 1 lancar di jamin dengan Rp. 2,42 aktiva lancar. Pada tahun 2017 ke tahun 2018 current ratio mengalami penurunan sebesar 47,7\% selisih dari 242,8\% - 195,1\%. Walapun mengalami penurunan yang tergolong besar current ratio PT indofood masih tergolong baik. berarti setiap Rp. 1 lancar di jamin dengan Rp. 1,9 aktiva lancar

\subsubsection{Quick Ratio}

Untuk prinsip kehati-hatian perusahaan, maka besarnya quick ratio dianggap baik adalah $100 \%$ (Kasmir, 2008) atau 1:1. Artinya kewajiban jangka pendek 100\% dijamin oleh aset lancar selain persediaan sebesar $100 \%$. Semakin tinggi nilai rasio maka menunjukkan semakin baik pula kinerja keuangan yang dicapai oleh perusahaan. pada tahun 2015 PT indofood memiliki quick ratio 190,1\%. Dari data 
tersebut dapat kita ketahui bahwa quick ratio dianggap sangat baik dari standar baik 100\%. Berarti setiap Rp. 1 hutang lancar di jamin dengan Rp. 1,90 . Pada tahun 2015 ke tahun 2016 quick ratio mengalami peningkatan sebesar 2,5\% selisih dari 190,1\% 192,6\%. Dari data tersebut dapat di ketahui bahwa quick ratio di anggap sangat baik dari standar quick ratio yaitu 100\%. Berarti setiap Rp. 1 hutang lancar di jamin dengan Rp. 1,92 . Kemudian pada tahun 2016 ke tahun 2017 quicki ratio juga mengalami peningkatan sebesar 2,4\% selisih dari 192,6\% - 195\%. Dari data tersebut dapat kita ketahui bahwa quick ratio dianggap sangat baik dari standar baik 100\%. Berarti setiap Rp. 1 hutang lancar di jamin dengan Rp. 1,95. dan pada tahun 2017 ke tahun 2018 quick ratio penurunan sebesar 55,2\% diperoleh dari selisih 195\%-139,8\%. Penurunan pada tahun 2017 ke 2018. termasuk penurunan yang sangat besar walaupun begitu perusahaan masih bisa menjamin hutang jangka pendek nya. Dan quick ratio di anggap baik dari standar baik 100\%. Berarti setiap Rp. 1 hutang lancar di jamin dengan Rp. 1,39 aktiva lancar.

\subsubsection{Cash Ratio}

Standar rasio kas yang paling baik adalah sebesar 50\%, semakin mendekati standar industri maka semakin baik kinerja keuangan suatu perusahaan. pada tahun 2015 PT indofood memiliki cash ratio 127,5\%. Dari data tersebut dapat kita ketahui bahwa cash ratio dianggap sangat baik dari standar baik 30\%. Berarti setiap Rp. 1 hutang lancar di jamin dengan Rp. 1,27 kas. Pada tahun 2015 ke tahun 2016 cash ratio mengalami peningkatan sebesar 1,9\% selisih dari 127,5 -129,4\%. Dari data tersebut dapat di ketahui bahwa cash ratio di anggap sangat baik dari standar baik cash ratio yaitu 30\%. Berarti setiap Rp. 1 hutang lancar di jamin dengan Rp. 1,29 kas. Kemudian pada tahun 2016 ke tahun 2017 cash ratio mengalami penurunan sebesar $0,06 \%$ selisih dari $129,4 \%-128,8 \%$. Walapun mengalami penurunan dapat kita ketahui bahwa cash ratio dianggap sangat baik dari standar baik 30\%. Berarti setiap Rp. 1 hutang lancar di jamin dengan Rp. 1,28 kas. dan pada tahun 2017 ke tahun 2018 rasio cepat mengalami penurunan sebesar 63,5\% diperoleh dari selisih 128,8\%$65,3 \%$. Penurunan pada tahun 2017 ke 2018. termasuk penurunan yang sangat besar tetapi masih tergolong sangat baik dari standar baik yaitu 30\%. Berarti setiap Rp. 1 hutang lancar di jamin dengan Rp. 0,65 kas

\section{KESIMPULAN DAN SARAN}

\subsection{Kesimpulan}

Berdasarkan analisis yang telah di lakukan pada laporan keuangan PT Indofood Sukses Makmur bisa kita simpulakan bahwa:

1. Kinerja keuangan PT indofood selama 4 tahun berdasarkan current ratio nya di nyatakan sangat baik berada di atas angka $200 \%$ atau 2:1. Hanya saja pada tahun 2018 menurun di bawah angka 200\% tetapi masih dalam kondisi sangat baik dan dapat dikatakan bisa melunasi hutang jangka pendek nya.

2. Kinerja keuangan PT indofood selama 4 tahun berdasarkan quick ratio nya di nyatakan sangat baik berada di atas angka $100 \%$ atau 1:1 dan dapat di katakan mampu melunasi hutang lancar nya.

3. Kinerja keuangan PT indofood selama 4 tahun berdasarkan cash ratio nya di nyatakan sangat baik yaitu dia atas $100 \%$ atau 1:1 dan di artikan mampu melunasi hutang lancar nya. Hanya saja pada tahun 2018 PT Indofood belom bisa melunasi hutang lancar nya dengan presentase angka di bawah $100 \%$. 
a. Saran

Sebaik nya PT Indofood mengurangi hutang jangka pendek dan meningkat kan jumlah kas pada tahun 2018. Supaya PT Indofood bisa melunasi hutang jangka pendek nya dengan menggunkan kas perusahaan nya.

\section{DAFTAR PUSTAKA}

Andayani, M. (2016). Analisis Rasio Likuiditas dan Rasio Profitabilitas Terhadap Perubahan Laba. Jurnal Ilmu dan Riset Akuntansi, 5(7), 4.

Arikunto, S. (2006). Prosedur Penelitian Suatu Pendekatan Praktis. Jakarta : Bima Aksara.

Barus, M. A., Sudjana, N., \& Sulasmiyati, S. (2013). Penggunaan Rasio Keuangan Untuk Mengukur Kinerja Keuangan Perusahaan. Jurnal Administrasi Bisnis (JAB), 44(1), 155.

Departemen Pendidikan Indonesia (2008). Kamus Besar Bahasa Indonesia. Jakarta : BalaiPustaka.

Fahmi, I. (2011). Analisa Laporan Keuangan. Bandung : Alfabeta.

Harahap, S. S. (2009). Teori Kritis Laporan Keuangan. Jakarta: Bumu Aksara.

Hardiningsih, P. (2006). Aplikasi Analisis Multivariate Dengan SPSS. Semarang:Universitas Diponegoro.

Harmono. (2011). Manajemen Keuangan. Jakarta : Bumi Aksara.

Haq, M. (2013). Analisis Rasio Keuangan. E-Journal Ilmu dan RisetManajemen, 2(1), 1.

Hery. (2015). Analisis Laporan Keuangan. Yogyakarta : CAPS.

Ikhsan, A. (2016). Analisa Laporan Keuangan. Medan: Madenatera.

Ikatan Akuntansi Indonesia. (2002). Standar Akuntansi Keuangan. Jakarta :

Salemba Empat.

Kasmir. (2008). Analsis Laporan Keuangan. Jakarta: Raja Grafindo Persada.

Machoedz, M. dan Mahmudi. (2008). Materi Pokok Akuntansi Manajemen. Jakarta

Universitas Terbuka.

Munawir, H. S. (2016). Analisa Laporan Keuangan. Yogyakarta : Liberty Yogyakarta.

Nawawi, H. (2003). Manajemen Sumber Daya Manusia Untuk Bisnis yang Kompetitif.Yogyakarta : Universitas Gajah Mada Press.

Ridwan. (2006). Metode dan Teknik Penyusunan Tesis. Bandung : Alfabeta.

Riyanto, B. (2008). Dasar-Dasar Pembelajaran Perusahaan. Yogyakarta : Penerbit GPFE. 